\title{
Biomineralization of carbonate and phosphate by moderately halophilic bacteria
}

\author{
Mónica Sánchez-Román ${ }^{1}$, Maria A. Rivadeneyra ${ }^{2}$, Crisogono Vasconcelos ${ }^{1}$ \& Judith A. McKenzie ${ }^{1}$ \\ ${ }^{1}$ Geological Institute, ETH-Zentrum, Zürich, Switzerland; and ${ }^{2}$ Department of Microbiology, Faculty of Pharmacy, University of Granada, Spain
}

\author{
Correspondence: Mónica Sánchez-Román, \\ Geological Institute, Earth Sciences \\ department (ETH) 1, Universitätstrasse 16, \\ 8092 Zürich, Switzerland. Tel.: +41 \\ 446320706; fax: +41446321075 ; \\ e-mail: monica.sanchez@erdw.ethz.ch
}

Received 6 November 2006; revised 5 March 2007; accepted 20 March 2007.

First published online 30 May 2007.

DOI:10.1111/j.1574-6941.2007.00336.x

Editor: Riks Laanbroek

Keywords

struvite; calcite; Mg-calcite; coprecipitated; moderately halophilic bacteria.

\begin{abstract}
We investigated the precipitation of carbonate and phosphate minerals by 19 species of moderately halophilic bacteria using media with variable $\mathrm{Mg}^{2+} / \mathrm{Ca}^{2+}$ ratios. The precipitated minerals were calcite, magnesium $(\mathrm{Mg})$ calcite, and struvite $\left(\mathrm{MgNH}_{4} \mathrm{PO}_{4} \cdot 6 \mathrm{H}_{2} \mathrm{O}\right)$ in variable proportions depending on the $\mathrm{Mg}^{2+}$ / $\mathrm{Ca}^{2+}$ ratio of the medium. The Mg content of the Mg-calcite decreased with increasing $\mathrm{Ca}^{2+}$ concentration in the medium. According to the saturation indices, other minerals could also have precipitated. We observed important differences between the morphology of carbonate and phosphate, which may help us to recognize these minerals in natural systems. We studied the growth and $\mathrm{pH}$ curves of four bacteria in media specific for carbonate and struvite precipitation. We consider the biomineralization processes that produce carbonate and phosphate minerals, and propose a hypothesis for the lack of struvite in natural environments and ancient rocks.
\end{abstract}

\section{Introduction}

The influence of microorganisms in mineral precipitation has been recognized for a wide variety of minerals (Ehrlich, 2002). Extensive literature exists on microbial involvement in carbonate precipitation in natural environments and laboratory experiments (Krumbein, 1979; Rivadeneyra et al., 1985a b, 1994; Vasconcelos \& McKenzie, 1997; Rivadeneyra et al., 2004; Sánchez-Román et al., 2007). In general, calcium carbonate biomineralization is not necessarily linked to any particular group of organisms or specific metabolic processes and is found widely distributed in many different natural environments.

In contrast to the fact that carbonate minerals are very abundant on the Earth's surface, struvite $\left(\mathrm{MgNH}_{4} \mathrm{PO}_{4}\right.$. $\left.6 \mathrm{H}_{2} \mathrm{O}\right)$ rarely occurs in nature. It has been found in association with organic matter decomposition, for example in barns and cemetery soils, and in guano deposits, manures and sediments rich in organic remains (Robison, 1889; Dana, 1997; Nriagu \& Moore, 1984; Donovan et al., 2005). Moreover, struvite is an important constituent of kidney stones (Griffith, 1978; McLean et al., 1985; Grases et al., 1996) and is frequently produced in wastewater treatment plants (Williams, 1999). Several authors have connected the precipitation of struvite in various natural habitats with microbial activity and have reported struvite production by a number of bacterial strains (Robison, 1889; Beavon \& Heatley, 1962; Rivadeneyra et al., 1983, 1992a; Da Silva et al., 2000). However, the microbial mediation of struvite precipitation does not appear to be as widespread, nor is it as well investigated, as the microbial precipitation of carbonates.

In studies of mineral precipitation by bacteria, several physicochemical parameters are considered to optimize mineral growth. Among these, the ionic composition and concentration of the solution appear to be the most important parameters for precipitation. Moderately halophilic bacteria can grow in solutions with a wide range of salinities, and they constitute a very useful group of microorganisms for determining how the ionic concentration and composition of the environment affect the precipitation of minerals by bacteria. A number of investigations have shown carbonate precipitation by some moderately halophilic bacteria and have demonstrated the importance of the $\mathrm{Mg}^{2+}$ concentration, as well as of the $\mathrm{Mg}^{2+} / \mathrm{Ca}^{2+}$ ratio, for precipitation (Ferrer et al., 1988; Rivadeneyra et al., 1994, 2000, 2004). Recently, struvite and carbonate precipitation have been observed in aerobic cultures of Chromohalobacter marismortui (Rivadeneyra et al., 2006). However, struvite precipitation by moderately halophilic bacteria has not been studied as thoroughly as for carbonates. We propose that a combined study of struvite and carbonate precipitation 
mediated by moderately halophilic bacteria could provide information to elucidate the factors controlling the coprecipitation of both struvite and carbonate minerals in natural saline environments.

In this paper, we present our study of the formation of struvite and carbonates by 19 species of Gram-negative, moderately halophilic bacteria. By varying the $\mathrm{Ca}^{2+}$ ion concentrations and $\mathrm{Mg}^{2+} / \mathrm{Ca}^{2+}$ ratios, we studied the influence of these variables on the precipitation of the two minerals. All the above-mentioned studies were carried out using artificial seawater, which, in addition to calcium and magnesium, contains other ions, such as sulfate, that can influence the precipitation and alter or modify the activity of the solution. In the present study, to avoid the possible influence of other inorganic ions, we used calcium and magnesium acetate as ionic sources and sodium chloride to obtain a saline concentration that would allow the growth of moderately halophilic bacteria. Both $\mathrm{Na}^{+}$and $\mathrm{Cl}^{-}$ions exert a weak or no influence on the precipitation of carbonates (Cailleau et al., 1977; Rivadeneyra et al., 1991). The extent of precipitation and the morphology and mineralogy of the minerals formed were also studied. In order to understand better the role of bacteria in precipitation, we studied the growth and $\mathrm{pH}$ curves of four bacteria in specific media for carbonate and struvite precipitation, and calculated the mineral saturation indexes in all the culture media using the geochemical program PHREeQC (Parkhust \& Appelo, 1999). Finally, we discuss the mechanism of formation of both minerals and the involvement of moderately halophilic bacteria in mineral precipitation in natural environments.

\section{Materials and methods}

\section{Microorganisms}

Nineteen Gram-negative bacterial strains of moderately halophilic bacteria were used in this study: 16 species of the genus Halomonas ( $H$. aquamarina ATCC 14400, $H$. canadiensis ATCC 43984, H. cupida ATCC 27124, H. elongata ATCC 33173, H. eurihalina ATCC 49509, H. halmophila ATCC 19717, H. halodenitrificans ATCC 13511, H. halodurans ATCC 29686, H. halophila CCM 3662 H. marina ATCC 25374, H. pacifica ATCC 27122, H. pantelleriense DSM 9661, $H$. salina ATCC 49509, $H$. subglaciescola ACAM 12, $H$. variabilis DSM 3051 and H. venusta ATCC 27125); Salinivibrio costicola NCIMB 701; Marinomonas communis DSM 5604; and Marinobacter hydrocarbonoclasticus ATCC 49840.

\section{Culture media}

The culture media used in this study are designated ME, MEC1, MEC2, MEC3, MEC4 and MC. The composition of the media was as follows $(\mathrm{w} / \mathrm{v}): 1 \%$ yeast extract, $0.5 \%$ proteose peptone, $0.1 \%$ glucose, supplemented with $\mathrm{NaCl}$ to
Table 1. Calcium and magnesium composition $\left(\mathrm{gL}^{-1}\right)$ and $\mathrm{Mg} / \mathrm{Ca}$ molar ratio in various culture media

\begin{tabular}{llllll}
\hline Medium & $\begin{array}{l}\mathrm{C}_{4} \mathrm{H}_{6} \mathrm{MgO}_{4} \cdot \\
4 \mathrm{H}_{2} \mathrm{O}\end{array}$ & $\begin{array}{l}\mathrm{C}_{4} \mathrm{H}_{6} \mathrm{CaO}_{4} \cdot \\
\mathrm{H}_{2} \mathrm{O}\end{array}$ & $\mathrm{Mg}^{2+}$ & $\mathrm{Ca}^{2+}$ & $\begin{array}{l}\mathrm{Mg} \mathrm{Ca}^{-1} \\
(\mathrm{M})\end{array}$ \\
\hline ME & 8 & - & 0.9 & - & - \\
MEC1 & 8 & 0.5 & 0.9 & 0.11 & 13.2 \\
MEC2 & 8 & 1 & 0.9 & 0.23 & 7.4 \\
MEC3 & 8 & 2 & 0.9 & 0.45 & 3.25 \\
MEC4 & 8 & 4 & 0.9 & 0.9 & 1.63 \\
MC & - & 4 & - & 0.9 & - \\
\hline
\end{tabular}

give a final concentration of $7.5 \%(\mathrm{w} / \mathrm{v})$. In addition, the media were amended with different concentrations of calcium acetate and/or magnesium acetate (Table 1), and the $\mathrm{pH}$ was adjusted to 7 with $0.1 \mathrm{M} \mathrm{KOH}$. To obtain a solid medium, $20 \mathrm{~g} \mathrm{~L}^{-1}$ Bacto-Agar was added.

\section{Study of mineral formation}

The 19 strains were surface-inoculated onto different solid media, incubated aerobically at $32^{\circ} \mathrm{C}$, and examined periodically with an optical microscope for the presence of minerals for up to 30 days after inoculation. The experiments were carried out in triplicate and were repeated three times. Controls consisting of uninoculated culture media and media inoculated with autoclaved bacterial cells were included in all experiments. $\mathrm{pH}$ measurements were performed at the end of the growth and mineral formation experiments. pH-indicator paper (Merck Spezial-Indikatorpapier) was directly applied on the semi-solid surface.

The minerals formed by all bacterial strains in the various media assayed were isolated, purified and identified. Struvite crystals were extracted from the solid agar media by means of a small spatula, washed with distilled water to free them of impurities, and air-dried at $37^{\circ} \mathrm{C}$. Carbonate crystals were removed from the solid media by cutting out pieces, which were placed in boiling water to dissolve the agar. The supernatants and the sediments were resuspended and washed in distilled water to free them of impurities. In this treatment $\mathrm{CO}_{3} \mathrm{Ca}$ dissolution was not significant, and the morphology of crystals was not altered, as observed by optical microscopy before and after their recovery. The washed carbonate crystals were finally air-dried at $37^{\circ} \mathrm{C}$.

\section{Mineral analysis}

The purified crystals were examined by X-ray diffraction (XRD) using an XDS 2000 Scintag INC, with a $\varnothing / \varnothing$ 'Goniometer and Peltier Detector'. The Mg:Ca ratio of the carbonate minerals was calculated from the $\mathrm{d}_{104}$ peak of the diffraction spectra after Lumsden (1979). A CAMSCAN CS44 scanning electron microscope (SEM), equipped with a spectroscope of dispersive energy (EDX), was used for imaging and elemental analysis of single crystals. 
Table 2. Number of days to initiate struvite $(S)$ and carbonate (C) precipitation with the bacteria investigated

\begin{tabular}{|c|c|c|c|c|c|c|c|c|c|c|c|c|}
\hline \multirow[b]{3}{*}{ Bacteria strain } & \multicolumn{12}{|c|}{ Medium and type of crystals formed } \\
\hline & \multicolumn{2}{|l|}{$\mathrm{ME}$} & \multicolumn{2}{|c|}{ MEC1 } & \multicolumn{2}{|c|}{ MEC2 } & \multicolumn{2}{|c|}{ MEC3 } & \multicolumn{2}{|c|}{ MEC4 } & \multicolumn{2}{|c|}{ MC } \\
\hline & S & $\mathrm{C}$ & S & $C$ & S & C & S & C & $\mathrm{S}$ & C & $S$ & $C$ \\
\hline Halomonas aquamarina ATCC 14400 & 7 & - & 8 & - & 12 & 10 & 15 & 8 & 20 & 5 & - & 3 \\
\hline Halomonas canadiensis ATCC 43984 & 8 & - & 9 & - & 10 & 10 & 17 & 6 & 19 & 5 & - & 3 \\
\hline Halomonas cupida ATCC 27124 & 9 & - & 13 & - & 12 & 15 & 18 & 8 & 22 & 5 & - & 4 \\
\hline Halomonas elongata ATCC 33173 & 7 & - & 9 & - & 10 & 15 & 19 & 6 & 20 & 4 & - & 4 \\
\hline Halomonas eurihalina ATCC 49509 & 8 & - & 10 & - & 10 & 12 & 17 & 7 & 20 & 5 & - & 4 \\
\hline Halomonas halmophila ATCC 19717 & 8 & - & 9 & - & 10 & 15 & 17 & 7 & 18 & 5 & - & 3 \\
\hline Halomonas halodenitrificans ATCC 13511 & 10 & - & 10 & - & 12 & 15 & 17 & 9 & 20 & 6 & - & 4 \\
\hline Halomonas halodurans ATCC 29686 & 7 & - & 8 & - & 11 & 15 & 18 & 8 & 20 & 5 & - & 4 \\
\hline Halomonas halophila CCM 3662 & 8 & - & 10 & - & 10 & 16 & 17 & 6 & 20 & 6 & - & 6 \\
\hline Halomonas marina ATCC 25374 & 8 & - & 10 & - & 10 & 14 & 17 & 8 & 20 & 6 & - & 4 \\
\hline Halomonas pacifica ATCC 27122 & 8 & - & 9 & - & 12 & 15 & 18 & 7 & 20 & 5 & - & 4 \\
\hline Halomonas pantelleriense DSM 3051 & 7 & - & 10 & - & 10 & 14 & 17 & 7 & 19 & 5 & - & 4 \\
\hline Halomonas salina ATCC 49509 & 8 & - & 11 & - & 10 & 15 & 17 & 7 & 19 & 6 & - & 4 \\
\hline Halomonas subglaciescola ACAM 12 & 7 & - & 10 & - & 9 & 14 & 17 & 7 & 20 & 6 & - & 5 \\
\hline Halomonas variabilis DSM 3051 & 7 & - & 9 & - & 10 & 15 & 17 & 8 & 20 & 6 & - & 5 \\
\hline Halomonas venusta ATCC 27125 & 7 & - & 12 & - & 13 & 16 & 18 & 7 & 18 & 5 & - & 4 \\
\hline Salinivibrio costicola NCIMB 701 & 8 & - & 10 & - & 11 & 15 & 18 & 8 & 20 & 6 & - & 5 \\
\hline Marinomonas communis DSM 5604 & 10 & - & 9 & - & 12 & 15 & 17 & 8 & 22 & 5 & - & 5 \\
\hline Marinobacter hydrocarbonoclasticus ATCC 49840 & 8 & - & 8 & - & 13 & 17 & 18 & 9 & 22 & 5 & - & 5 \\
\hline
\end{tabular}

ATCC, American Type Culture Collection; CCM, Czech Collection of Microorganisms; DSM, Deutsche Sammlung von Mikroorganismen; ACAM, Australian Collection of Antartic Microorganisms; NCIMB, Natural Collection of Industrial Food and Marine Bacteria.

\section{Geochemical study}

The activity of dissolved species and the degree of saturation in the solutions assayed were determined using the geochemical computer program PHREEQC version 2 (Parkhust \& Appelo, 1999). The results from PHREEQC are presented in terms of the saturation index (SI) for each predicted mineral. SI is defined by $\mathrm{SI}=\lg \left(\mathrm{IAP} / \mathrm{K}_{\mathrm{sp}}\right)$, where IAP is the ion activity product of the dissolved mineral constituents in a solubility product $\left(\mathrm{K}_{\mathrm{sp}}\right)$ for the mineral. Thus, $\mathrm{SI}>0$ implies oversaturation with respect to the mineral, whereas SI $<0$ means undersaturation.

All calculations were performed applying the following values $\left(\mathrm{gL}^{-1}\right): \mathrm{Mg}^{2+}$ and $\mathrm{Ca}^{2+}$, see Table $1, \mathrm{Na}^{+}=29.58$, $\mathrm{Cl}^{-}=45.51, P=0.15\left(\mathrm{PO}_{4}^{3-}=0.46\right)$ and $\mathrm{NH}_{4}^{+}=1.73$. The values of $\mathrm{Na}^{+}, \mathrm{Cl}^{-}, \mathrm{P}$ and $\mathrm{NH}_{4}^{+}$correspond to the addition of $\mathrm{NaCl}=75 \mathrm{gL}^{-1}$, proteose peptone $=5 \mathrm{gL}^{-1}$ and yeast extract $=10 \mathrm{~g} \mathrm{~L}^{-1}$. Total nitrogen in the culture media was determined by Kjeldhal's method, while total phosphorus was determined colorimetrically in the nitrogen digests, generating the phosphomolibdic complex (Page et al., 1982).

\section{Growth and pH curves}

To evaluate growth and $\mathrm{pH}$ curves, we selected four bacteria (H. aquamarina, H. pacifica, S. costicola and M. hydrocarbonoclasticus), which were grown in the struvite-specific medium ME and in the carbonate-specific medium MC.
Liquid cultures were carried out in 500-mL Erlenmeyer flasks containing $200 \mathrm{~mL}$ of either the ME or MC medium. Bacterial growth was evaluated by following changes in the $\mathrm{OD}$ at a wavelength of $580 \mathrm{~nm}$ using a Cintra 10e spectrophotometer. In addition, we measured the $\mathrm{pH}$ of the solutions using a Crison $\mathrm{pH}$ meter Basic 20.

\section{Results}

Struvite and/or carbonate precipitation was observed with all bacterial species tested. Table 2 shows the time, in days, required to observe precipitation for each one of the bacterial strains investigated in the various culture media. Table 3 shows the results of mineralogical analysis of the crystals formed in the media according to the XRD study. Struvite was not observed to form in the MC medium, which is specific for calcium carbonate precipitation. Calcium carbonate was not formed in the ME medium, which is specific for struvite precipitation, nor in the MEC1 medium. In the MEC2, MEC3 and MEC4 media, struvite and $\mathrm{Mg}$-calcite coprecipitated in different proportions depending on the culture medium assayed; that is, with increasing $\mathrm{Ca}^{2+}$ ion concentration, the amount of $\mathrm{Mg}$ calcite precipitated was greater than the amount of struvite. The $\mathrm{Ca}^{2+}$ and $\mathrm{Mg}^{2+}$ contents of the Mg-calcite precipitates in these cultures are indicated by the formulas given in Table 3, which represent an average value for the carbonate precipitates by all bacteria investigated. No precipitation of 
Table 3. Mineralogy of the precipitates derived from the XRD analysis

\begin{tabular}{llll}
\hline Medium & Mineral (\%) & $\mathrm{d}_{104}(\AA)$ for carbonate & *Formula for carbonate \\
\hline ME & Struvite (100\%) & - & - \\
MEC1 & Struvite (100\%) & - & - \\
MEC2 & Struvite (40\%), Mg-calcite (60\%) & 2.949 & $\mathrm{Ca}_{0.71} \mathrm{Mg}_{0.29} \mathrm{CO}_{3}$ \\
MEC3 & Struvite (30\%), Mg-calcite (70\%) & 2.976 & $\mathrm{Ca}_{0.80} \mathrm{Mg}_{0.20} \mathrm{CO}_{3}$ \\
MEC4 & Struvite (20\%), Mg-calcite (80\%) & 2.996 & $\mathrm{Ca}_{0.87} \mathrm{Mg}_{0.13} \mathrm{CO}_{3}$ \\
MC & Calcite (100\%) & 0.303 & $\mathrm{CaCO}_{3}$ \\
\hline
\end{tabular}

*The formulas for carbonate minerals were obtained from the $d_{104}$ peak of the diffraction spectra according to Lumsden (1979).
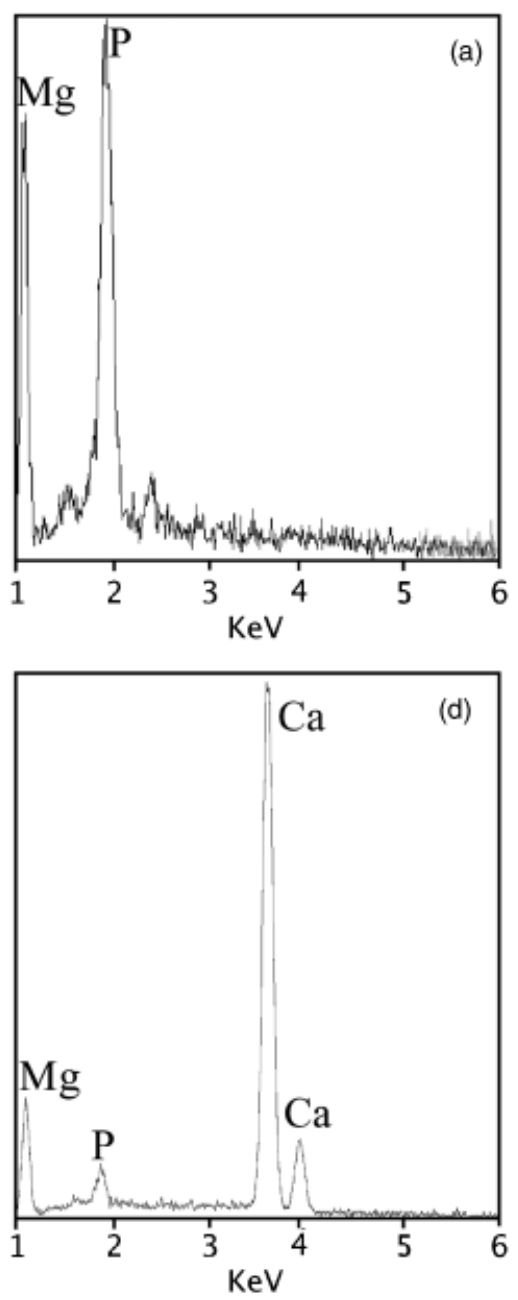
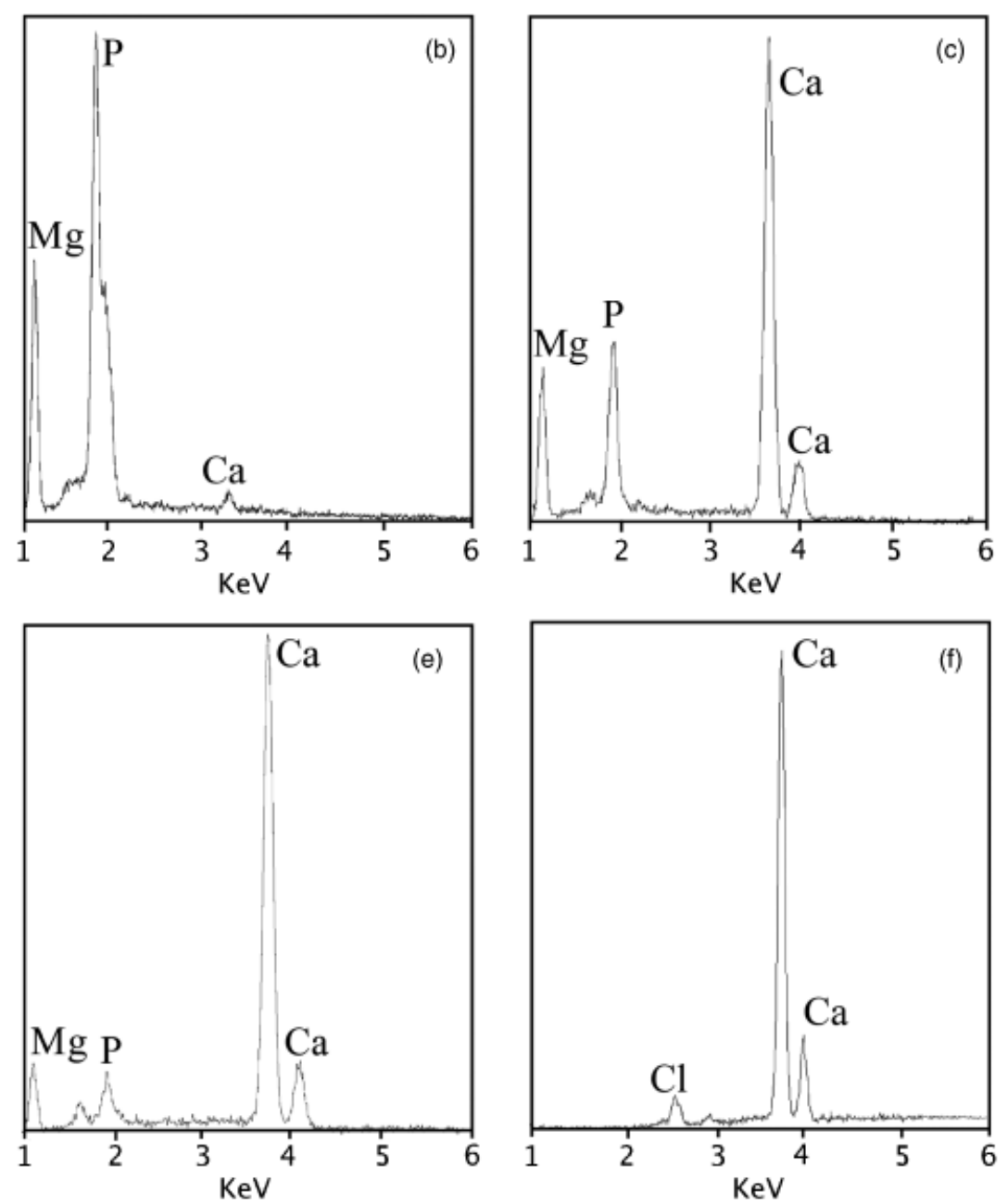

Fig. 1. EDX spectra of the mineral precipitates: (a) struvite (ME medium); (b) struvite with low content of Ca (MEC1 medium); (c) high Mg-calcite biolith with abundant organic matter (MEC2 medium); (d) Mg-calcite (MEC3 medium); (e) low Mg-calcite (MEC4 medium); and (f) calcite (MC medium).

either struvite or carbonate was detected in the control experiments. A significant rise in $\mathrm{pH}$ occurred in both liquid and solid cultures with living bacteria, from the original $\mathrm{pH}$ 7.2 of the medium up to $c .9$. No change in $\mathrm{pH}$ was detected in the control experiments.

EDX microanalyses of isolated single struvite crystals and of bioliths from samples with different mineralogies confirm the XRD results (Fig. 1). The stoichiometry of struvite crystals is well defined by a nearly constant intensity ratio of $\mathrm{P}$ and $\mathrm{Mg}$ (Fig. 1a and b). Figure $\mathrm{lb}$ shows a struvite crystal with a low content of $\mathrm{Ca}^{2+}$. This crystal was precipitated in MEC1 medium, which has a low content of $\mathrm{Ca}^{2+}$. EDX spectra of carbonate bioliths indicate that some of them are composed of calcium carbonate. Minerals 
precipitated in the MC medium are composed of calcite (Fig. 1f), whereas variable amounts of $\mathrm{Mg}^{2+}$ and $\mathrm{Ca}^{2+}$ are present in those formed in MEC2, MEC3 and MEC4 media, varying from high $\mathrm{Mg}$-calcite (Fig. $1 \mathrm{c}$ and d) to low $\mathrm{Mg}$ calcite (Fig. 1e) in accordance with the XRD study (see Table 3). Small amounts of $\mathrm{P}_{\text {and }} \mathrm{Cl}^{-}$are usually present together with $\mathrm{Ca}^{2+}$ and $\mathrm{Mg}^{2+}$ in the microanalyses of the carbonate bioliths formed in the media, but their occurrence is interpreted to be directly derived from the elements of the culture medium, as a result of incomplete washing of dead bacterial remains and pellicles together with organic matter from the culture medium.

In all cultures, the size and quantity of crystals increased with longer incubation times. With increasing $\mathrm{Ca}^{2+}$ ion concentration in the culture media, we observed that: (1) the $\mathrm{Mg}^{2+}$ content in calcite decreased (see Fig. 1c-e and Table $3)$; (2) the time required for struvite precipitation increased (Table 2) and the amount of precipitate decreased (Table 3); and (3) the time required for carbonate precipitation decreased (Table 2) and the amount of precipitate increased (Table 3). Another observation worth mentioning is that struvite formed before carbonate in the MEC2 medium, whereas carbonate formed before struvite in the MEC3 and MEC4 media.

Normally, struvite precipitation began at the edge of the bacterial mass, and within a short time more crystals appeared until they completely covered the bacterial mass. We observed crystals of struvite with a variety of morphologies, the most common having a tabular form (Fig. 2). In general, carbonate precipitation began at the edge of the bacterial mass, forming a ring that grew wider with incubation time. Spherulites were the most frequent morphology, although we observed other morphologies, such as dumbbells (Fig. 3). Smooth and rough surfaces were observed for the spherulites, as well as some with fibrous internal structures.

Table 4 shows the mineral phases with SI values positive or very close to 0 (above or below the equilibrium point), suggesting the possibility for inorganic precipitation in the media assayed. These SI data were obtained by applying the geochemical computer program PHREEQC to the ionic composition of the various culture media (Table 4). According to these data, the ME medium (without $\mathrm{Ca}^{2+}$ ) is undersaturated in hydromagnesite and saturated in struvite. The MC medium (without $\mathrm{Mg}^{2+}$ ) is saturated in calcite and aragonite and supersaturated in hydroxyapatite. The MEC1, MEC2, MEC3 and MEC4 media is saturated in aragonite, calcite and dolomite and supersaturated in hydroxyapatite and struvite. The increase of calcium concentration slightly favours the formation of aragonite, calcite, dolomite and hydroxyapatite.

The growth and $\mathrm{pH}$ curves of the four selected bacteria in the ME and MC media are shown in Fig. 4. In all cultures, we observed mineral precipitation in the stationary phase. In both media and for all four bacteria investigated we observed a decrease in $\mathrm{pH}$ at the beginning of the culture experiments owing to the bacterial degradation of acetate and glucose, which produces elevated concentrations of $\mathrm{CO}_{2}$. Subsequently, alkalinization of the media occurred as a consequence of the ammonium released by the bacterial degradation of peptones and yeast extracts with increasing $\mathrm{pH}$. The precipitation of both struvite and calcite occurred when the media became alkaline.

\section{Discussion}

\section{Bacterial precipitation of carbonate and phosphate: Influence of $\mathrm{Ca}^{2+}$ and $\mathrm{Mg}^{2+}$ ions}

Stumm \& Morgan (1996) linked the C and P cycles, describing the transformation of calcite into apatite as a function of $\mathrm{pH}$ and phosphate concentration in the medium. In the present study, we also link the $\mathrm{C}$ and $\mathrm{P}$ cycles, as we observe $\mathrm{Mg}$-calcite and struvite coprecipitation in the same bacteria cultures. In addition, we discuss how phosphate mineral precipitation favours carbonate precipitation and vice versa.

Biologically induced biomineralization is defined as a process of mineral formation by organisms in an open medium without the participation of macromolecules or specific cells (Lowenstam \& Weiner, 1989). In accordance with this definition, the processes described in this study can be considered as biologically induced biomineralization because the chemical modifications of the medium create suitable conditions for mineral precipitation as a result of the metabolic activity of these microorganisms and ions concentration in the external envelopes of the bacteria. Biologically induced precipitation has been previously described for carbonate and calcium phosphate minerals (Benzerara et al., 2004; Rivadeneyra et al., 2004).

Rivadeneyra et al. (1983) observed in experiments with nonhalophilic bacteria that all the bacteria that mediated struvite precipitation were also capable of precipitating carbonate, but not the reverse. This indicates that the bacteria are more suited for carbonate precipitation than for struvite precipitation. In contrast, all the moderately halophilic bacteria investigated in the present study are capable of promoting the precipitation of both struvite and carbonate minerals. This result suggests that moderately halophilic bacteria are probably more adapted for the precipitation of struvite than are nonhalophilic bacteria. However, our results are also consistent with those of Rivadeneyra et al. (1983), because in the MEC2, MEC3 and MEC4 media we observed the precipitation of Mg-calcite, even though the media have high $\mathrm{Mg}^{2+}$ concentrations, which has been shown to have an inhibitory effect on the 

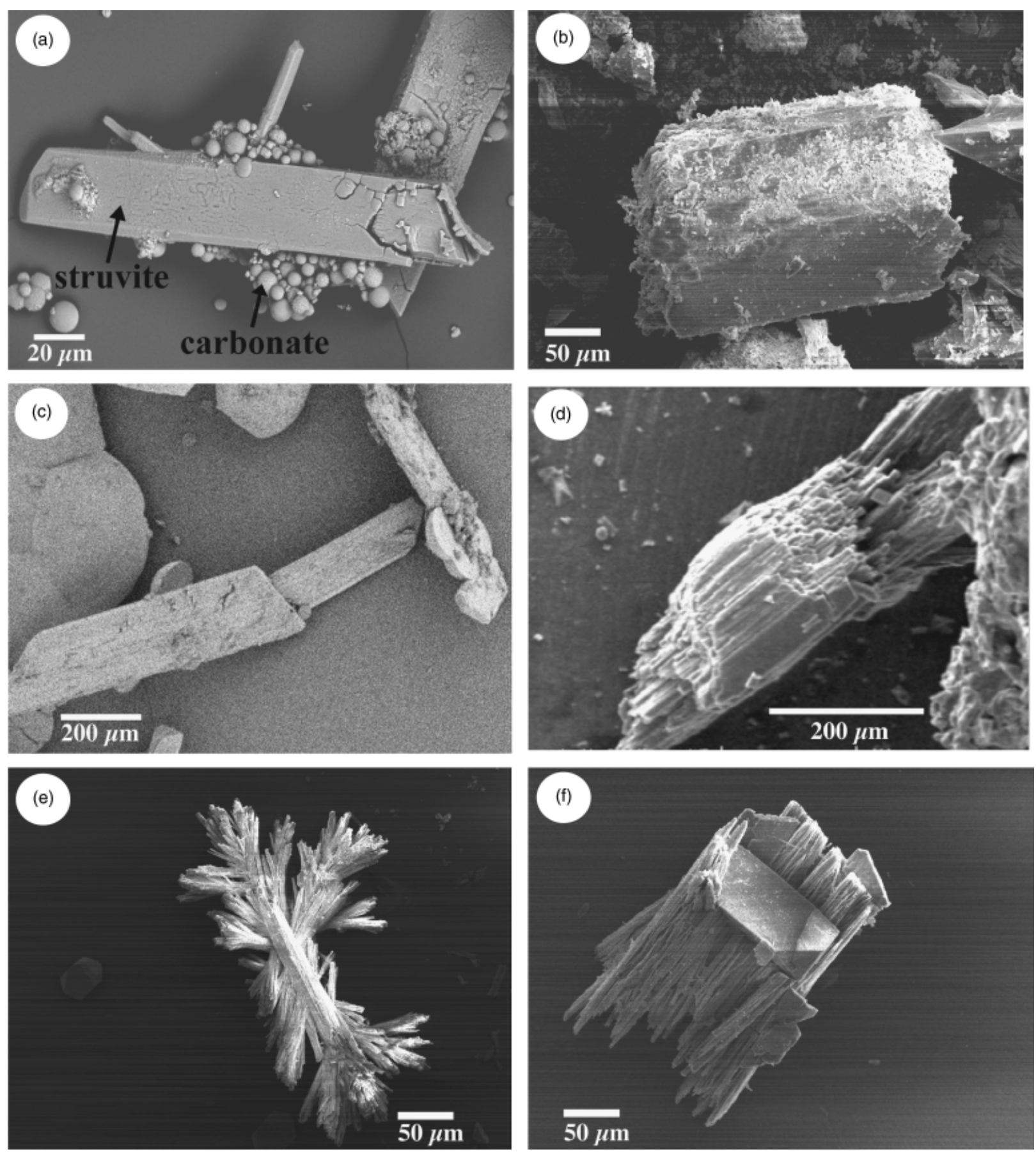

Fig. 2. Morphology of struvite crystals as observed by scanning electron microscopy (SEM): (a) overview showing struvite and carbonate crystals; and $(b-f)$ isolated struvite crystals with different morphologies.

nucleation and growth of calcite (Morse, 1983; Rivadeneyra et al., 1985a b; Ferrer et al., 1988; Rivadeneyra et al., 1991). Carbonate minerals did not form either in the medium ME (without $\mathrm{Ca}^{2+}$ ) or in the medium MEC1, which had a very low $\mathrm{Ca}^{2+}$ ion concentration $\left(0.11 \mathrm{~g} \mathrm{~L}^{-1}\right)$ and a high $\mathrm{Mg}^{2+}$ / $\mathrm{Ca}^{2+}$ ratio (13.2). In addition, comparing the precipitation of struvite with carbonate precipitation in their specific media (ME and MC, respectively), all bacteria produced large amounts of carbonate relative to struvite, and the precipitation of carbonate minerals was initiated before the precipitation of struvite (Table 2).

On the other hand, it has previously been reported that the presence of $\mathrm{Ca}^{2+}$ and $\mathrm{CO}_{3}^{2-}$ ions in media in which struvite precipitates can lengthen the induction time 

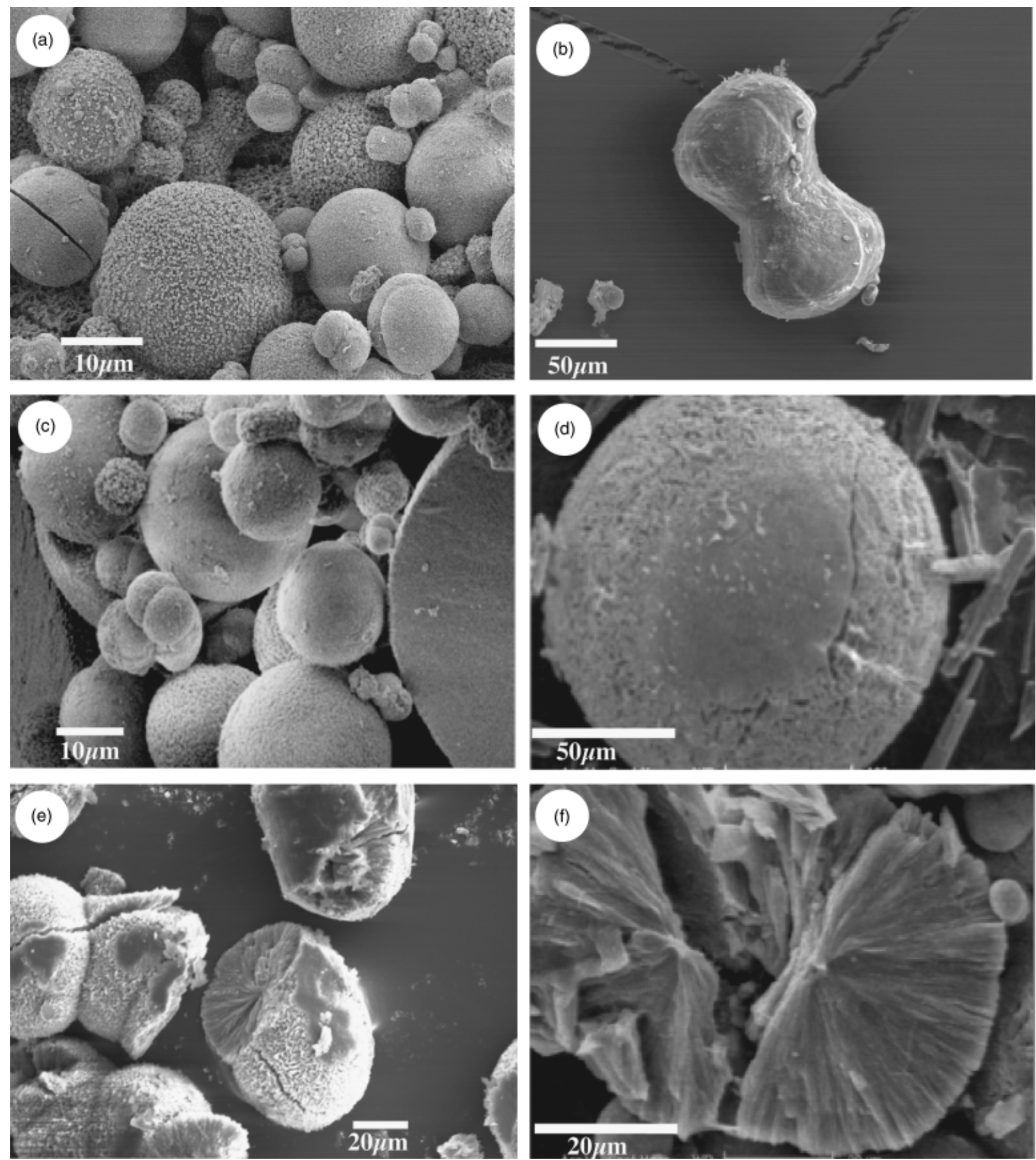

Fig. 3. Morphology of carbonate crystals as observed by scanning electron microscopy (SEM): (a) overview showing a mixture of morphologies; (b) dumbbell-shaped crystal; (c) smooth-faced spherical crystal; (d) rough-faced spherical crystal; (e) spherical crystal with fibrous internal structures; and (f) broken spherical crystal showing fibrous and cracked interior.

preceding the first occurrence of crystals and affect the growth rate negatively (Bouropoulos \& Koutsoukos, 2000; Kofina \& Koutsoukos, 2005). Moreover, in the biological precipitation of struvite, $\mathrm{Ca}^{2+}$ ions make struvite precipitation difficult and even inhibit it (Beavon \& Heatley, 1962;
Rivadeneyra et al., 1983). In part, our results confirm this observation. When the $\mathrm{Ca}^{2+}$ ion concentration is increased, the precipitation of struvite is slower, bacteria generally take longer to induce precipitation, and the amount of precipitate is smaller than without $\mathrm{Ca}^{2+}$ ions in the medium. 
Table 4. Saturation index values (SI) for minerals in all media assayed. Results are from the geochemical computer program PHREEQC

\begin{tabular}{lcccccc}
\hline & \multicolumn{2}{l}{ Culture medium } & & & \\
\cline { 2 - 6 } Mineral phase & ME & MEC1 & MEC2 & MEC3 & MEC4 & MC \\
\hline Halite, $\mathrm{NaCl}$ & -1.75 & -1.75 & -1.75 & -1.75 & -1.75 & -1.75 \\
Hydromagnesite, $\mathrm{Mg}_{5}\left(\mathrm{CO}_{3}\right)_{4}(\mathrm{OH})_{2} \cdot 4 \mathrm{H}_{2} \mathrm{O}$ & -9.01 & -8.92 & -8.85 & -8.72 & -8.49 & - \\
Struvite, $\mathrm{MgNH} \mathrm{PO}_{4} \cdot 6 \mathrm{H}_{2} \mathrm{O}$ & 11.23 & 11.22 & 11.21 & 11.20 & 11.17 & - \\
Aragonite, $\mathrm{CaCO}$ & - & -0.12 & 0.22 & 0.54 & 0.90 & 0.64 \\
Calcite, $\mathrm{CaCO}$ & - & 0.02 & 0.36 & 0.68 & 1.04 & 0.78 \\
Dolomite, $\mathrm{CaMg}\left(\mathrm{CO}_{3}\right)_{2}$ & - & 1.46 & 1.81 & 2.17 & 2.59 & - \\
Hydroxyapatite, $\mathrm{Ca}_{5}\left(\mathrm{PO}_{4}\right)_{3} \mathrm{OH}$ & - & 4.96 & 6.53 & 7.95 & 9.36 \\
\hline
\end{tabular}

Besides, in the MEC4 and MEC3 media with higher concentrations of $\mathrm{Ca}^{2+}$ ions, the precipitation of struvite always occurs after the precipitation of carbonate. Some authors have shown that the inhibitory effect of $\mathrm{Mg}^{2+}$ ions on calcite precipitation is significantly lower with moderately halophilic bacteria than with nonhalophilic ones (Ferrer et al., 1988; Rivadeneyra et al., 1994). Similarly, our results indicate that the effect of $\mathrm{Ca}^{2+}$ ions on struvite precipitation may be less inhibitory with moderately halophilic bacteria than with nonhalophilic ones, which is indicated by the fact that all bacteria investigated are capable of forming struvite with variable $\mathrm{Ca}^{2+}$ concentration in the medium. Although the increase of $\mathrm{Ca}^{2+}$ ion concentration negatively affects the precipitation of struvite, in all cultures assayed, a considerable amount of struvite was produced.

\section{Mechanisms of precipitation of carbonate and phosphate minerals}

Bacteria can serve as a nucleus for mineral precipitation by adsorbing cations around the cellular surface membrane, cell wall or extracellular polymeric substance (EPS) layers (Morita, 1980; Ferris et al., 1991; Braissant et al., 2003). According to Rosen (1987), however, the bacterial $\mathrm{Ca}^{2+}$ pump is located towards the exterior of the cell, and the $\mathrm{Mg}^{2+}$ pump towards the interior. In addition, the $\mathrm{Ca}^{2+}$ ion is adsorbed more frequently than the $\mathrm{Mg}^{2+}$ ion on the negatively charged cellular envelope of the bacteria because it has a greater power for ionic selectivity (Wolt, 1994; Maier et al., 2000). All these observations could explain the major tendency for the precipitation of carbonate minerals before struvite. Nevertheless, in the same culture, different bacteria mediate the precipitation of different proportions of struvite, calcite and $\mathrm{Mg}$-calcite. Furthermore, the Mg-calcite contains variable $\mathrm{Mg}$ concentrations, depending on the bacteria used and the medium assayed (Table 3; Fig. 1c-e). These observations lead us to conclude that there exist differences among bacteria concerning the capacity of their cellular envelope to adsorb variable concentrations of $\mathrm{Ca}^{2+}$ and $\mathrm{Mg}^{2+}$ ions, which is in agreement with Rivadeneyra et al. (2004), who proposed that different bacteria can create microenvironments with different proportions of $\mathrm{Ca}^{2+}$ and $\mathrm{Mg}^{2+}$ ions leading to the precipitation of different minerals.

Rivadeneyra et al. (1992b) proposed a mechanism for struvite precipitation in which the adsorption of $\mathrm{Mg}^{2+}$ and $\mathrm{PO}_{4}^{3-}$ ions, together with the release of the $\mathrm{NH}_{4}^{+}$ion, may be responsible for its formation. Another similar suggested mechanism for the precipitation of carbonates both in natural environments (Ehrlich, 2002) and in laboratory culture experiments (Rivadeneyra et al., 1996, 2004; Sánchez-Román et al., 2007) proposes that bacteria induce precipitation owing to the adsorption of $\mathrm{Ca}^{2+}$ and/or $\mathrm{Mg}^{2+}$ ions together with the production of $\mathrm{CO}_{3}^{2-}$ and $\mathrm{NH}_{4}^{+}$ions with increasing $\mathrm{pH}$. A similar mechanism may occur in our cultures because the media used in the present study contain $\mathrm{Ca}^{2+}$ and/or $\mathrm{Mg}^{2+}$ ions, as well as acetate, glucose, peptone and yeast extract as organic matter. The metabolization of this organic matter produces $\mathrm{CO}_{3}^{2-}, \mathrm{NH}_{4}^{+}$and $\mathrm{PO}_{4}^{3-}$ ions, which are required for the precipitation of struvite and carbonate minerals.

With both mechanisms, the metabolic activity of the bacteria is extremely important because it supplies the ions necessary for the formation of the minerals, namely $\mathrm{NH}_{4}^{+}$ and $\mathrm{PO}_{4}^{3-}$ for struvite or $\mathrm{CO}_{3}^{2-}$ for carbonates. Moreover, the appropriate microenvironment is created for precipitation, i.e. increased $\mathrm{pH}$ and/or ionic concentration. The importance of the metabolic activity in the process of biomineralization is supported by the fact that no precipitation was observed in the control experiments without bacteria or with autoclaved bacterial cells. This demonstrates that bacteria are not simply heterogeneous nuclei for precipitation but are active mediators in the process.

Based on the above results, the compounds degrading first in these cultures are acetate and glucose, with the consequent saturation of the media in $\mathrm{CO}_{2}$ and a decrease of $\mathrm{pH}$ (Fig. 4a). Subsequently, the degradation of peptones and yeast extract takes place, supplying $\mathrm{NH}_{4}^{+}$and $\mathrm{PO}_{4}^{3-}$ ions and leading to an increase of $\mathrm{pH}$, as observed in both solid and liquid culture experiments. The changes occurring in the media, together with the concentration of ions in the cellular envelopes, will drive local oversaturation of such ions, leading to carbonate and struvite precipitation. 

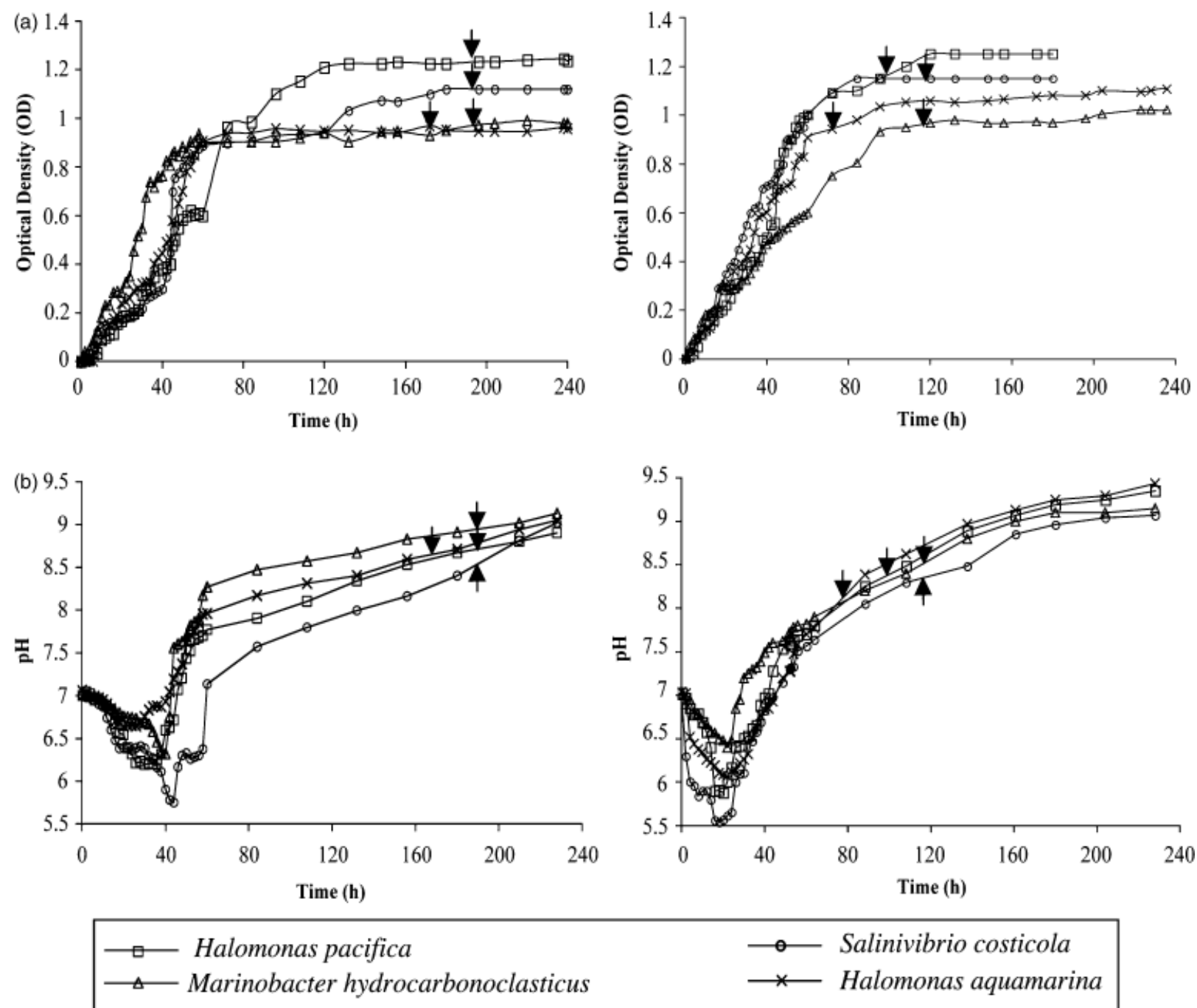

Fig. 4. Growth (a) and pH (b) curves of four selected bacteria in ME and MC media. Arrows indicate the starting of precipitation in each culture.

The results from XRD studies of the minerals precipitated and from geochemical studies of the culture media (Tables 3 and 4) show the following. (1) In the MC medium (without $\mathrm{Mg}^{2+}$ ), the geochemical conditions should be ideal for the formation of aragonite, calcite and particularly hydroxyapatite. In spite of this, only calcite precipitated in the MC medium. (2) In the MEC1, MEC2, MEC3 and MEC4 media (with various concentrations of $\mathrm{Ca}^{2+}$ and $\mathrm{Mg}^{2+}$ ions), aragonite, calcite, dolomite, hydromagnesite and mainly hydroxyapatite and struvite should precipitate. However, in the MEC1 medium, only struvite precipitated, and in the MEC2, MEC3 and MEC4 media, Mg-calcites and struvite precipitated. These results clearly show that bacteria exert some control in the process of precipitation. Thus, in media with high enough concentrations of $\mathrm{Ca}^{2+}$ ions, the bacteria investigated promote the precipitation of $\mathrm{Mg}$-calcite or calcite instead of hydroxyapatite. Furthermore, these results suggest that, in media with high enough concentrations of $\mathrm{Mg}^{2+}$ and $\mathrm{Ca}^{2+}$ ions (as well as of $\mathrm{CO}_{3}^{2-}, \mathrm{NH}_{4}^{+}$and $\mathrm{PO}_{4}^{3-}$ ions), the bacteria induce further calcium-magnesium carbonate precipitation instead of struvite.

We propose that the sequence of organic matter degradation detailed above could also be responsible for the results obtained. First of all, a high $\mathrm{CO}_{2}$ concentration is produced, which will lead to carbonate precipitation before a phosphate concentration for hydroxyapatite and/or struvite precipitation is obtained. We also have to take into account that in the first bacterial culture stages a large proportion of the phosphate released from the organic matter is used for bacterial growth, and such ions will be available for mineral precipitation only after the bacteria die. In accordance with this, in the bacteria growth curves (Fig. 4), we observe that struvite precipitation occurs at an advanced stage of the stationary phase and that all the bacteria strains investigated 
induce calcite precipitation before struvite precipitation. Moreover, we must consider that, in media with high $\mathrm{Mg}^{2+}$ and $\mathrm{NH}^{4+}$ ion concentrations, struvite precipitation will inhibit apatite precipitation and/or the transformation of calcite into apatite, as the amount of available phosphate will decrease.

The geochemical study supports this hypothesis because, if the final concentrations of $\mathrm{NH}_{4}^{+}\left(1.73 \mathrm{~g} \mathrm{~L}^{-1}\right)$ and $\mathrm{PO}_{4}^{3-}$ $\left(0.46 \mathrm{~g} \mathrm{~L}^{-1}\right)$ obtained after the metabolization of organic matter were available in all the media, struvite and/or hydroxyapatite should precipitate. However, other habitats with available phosphate and different sources of organic matter can modify the sequence of precipitation and/or the proportion of the precipitates. For example, in renal calculi or in urinary agregates, struvite is frequently found together with small amounts of apatite and calcite (Griffith et al., 1976; Cox et al., 1989). This is also the case for certain marine sediments (Stumm \& Morgan, 1996).

All the points detailed above could explain the differences often found between mineral precipitation induced by different microorganisms in different habitats and in pure inorganic media. Due to the fact that the bacteria, according to their metabolism and ability to concentrate ions inside their cells and/or in their cellular surface, modify the chemical composition of the media, creating microenvironments that favour the precipitation of different minerals, which are not expected to precipitate in inorganic media. The mineral precipitation in a given habitat is influenced by the mineral composition of the habitat and by the amount and kind of existing organic matter.

Our results also confirm that solid media hinder the precipitation of aragonite, as previously noted (Rivadeneyra et al., 1985a). In spite of the fact that most media were saturated with respect to aragonite, aragonite crystals never formed.

All the above-mentioned observations and the fact that in all cultures the size and quantity of crystals increased with increasing incubation time lead us to propose that, in MEC3 and MEC4, the precipitation of calcium and magnesium carbonates removes sufficient numbers of $\mathrm{CO}_{3}^{2-}$ and $\mathrm{Ca}^{2+}$ ions (increasing the $\mathrm{Mg}^{2+} / \mathrm{Ca}^{2+}$ ratio) to facilitate struvite precipitation. At the same time, the precipitation of struvite removes $\mathrm{Mg}^{2+}$ and $\mathrm{PO}_{4}^{3-}$ ions from the medium, leading to a major precipitation of carbonates. It should be noted that $\mathrm{Ca}^{2+}$ and/or $\mathrm{CO}_{3}^{2-}$ ions hinder the precipitation of struvite (Bouropoulos \& Koutsoukos, 2000; Kofina \& Koutsoukos, 2005), while $\mathrm{Mg}^{2+}$ and $\mathrm{PO}_{4}^{3-}$ ions hinder the precipitation of calcite (Morse, 1983; Rivadeneyra et al., 1985a, b, 1991). In the MEC2 medium with a low $\mathrm{Ca}^{2+}$ ion concentration $\left(0.23 \mathrm{~g} \mathrm{~L}^{-1}\right)$ and high $\mathrm{Mg}^{2+} / \mathrm{Ca}^{2+}$ ratio (7.4), the sequence of precipitation is inverted, indicating, possibly, that the removal of $\mathrm{Mg}^{2+}$ ions via struvite precipitation and the consequent decrease of the $\mathrm{Mg}^{2+} / \mathrm{Ca}^{2+}$ ratio promote carbonate precipitation. In the MEC1 medium, with very low $\mathrm{Ca}^{2+}$ ion concentration $\left(0.11 \mathrm{~g} \mathrm{~L}^{-1}\right)$ and high $\mathrm{Mg}^{2+}$ / $\mathrm{Ca}^{2+}$ ratio (13.2), only struvite precipitated, suggesting that, possibly, the incubation time (30 days) was not long enough to modify the medium and induce carbonate precipitation.

\section{Morphology of the precipitates}

Struvite and carbonate crystals have distinctly different morphologies, as is shown in Figs 2 and 3. In general, struvite crystals have polyhedral, pseudo-polyhedral or branching shapes, whereas carbonate crystals have spherical or dumbbell shapes. Other authors have observed similar morphologies for struvite (Rivadeneyra et al., 1983,1992a; Ben Omar et al., 1996) and carbonates (Ferrer et al., 1988; Buczynski \& Chafetz, 1991; Rivadeneyra et al., 1994; Vasconcelos \& McKenzie, 1997; Castanier et al., 1999; Rivadeneyra et al., 2004; Sánchez-Román et al., 2007). It is notable that phosphate and carbonate minerals formed in different cultures. Although the morphology alone is not a valid criterion for the identification of minerals, it can be used to select the best method to recover and purify the crystals. Whereas washing in boiling water is the best method to remove the solid agar media from the carbonate crystals, this method would lead to dehydration of the struvite and to problems with its identification.

Buczynski \& Chafetz (1991) suggested that dumbbell morphologies are unique to bacterially induced precipitates and that carbonate spherulites are the final stage of dumbbell growth. The investigated biocarbonate precipitates show both spheroidal and dumbbell morphologies, although the bioliths most frequently have a spherical shape and a fibrous radiated interior. The morphologies observed appear to be unique in that they are not specific to any particular bacterial genus or environment. They are also common to other biogenic carbonates, such as dolomite and aragonite (Vasconcelos \& McKenzie, 1997; Rivadeneyra et al., 2000; Sánchez-Román et al., 2007). Thus, the morphology of the bacterial precipitates may have important implications for the recognition and interpretation of microbial-mediated carbonate sediments and associated marine or continental microcrystalline carbonate cements, and contributes substantially to our understanding of recent carbonate formation and, possibly, to the identification of bacterial activity in the rock record.

\section{Coprecipitation of carbonate and struvite: implications for natural environments}

In this study we have observed that the carbon and phosphorus cycles are interrelated during biomineralization. In some media (e.g. MEC4 and MEC3), the precipitation of struvite is possible after the precipitation of carbonates. In other media, such as MEC2, conditions for the precipitation of carbonates are created after the 
precipitation of struvite. Although the main focus of the present study was not mineral precipitation in natural environments, we propose that our experimental observations provide information that could be used to interpret the role of microorganisms in diagenetic processes resulting in carbonate and phosphate precipitation in nature.

The fact that microorganisms play an important role in mineral precipitation in natural habits is widely accepted by many scientists, particularly the observation of bacterial carbonate precipitation by different mechanisms and in different environments (Ehrlich, 2002). However, studies of struvite precipitation and its ecological implications are rare, which may be a result of the scarcity of this mineral in natural environments and ancient rocks. We propose that the coprecipitation of carbonate and struvite may occur in nature, as in our laboratory culture experiments, when the natural conditions are suitable for the precipitation.

In nature, the carbonate minerals persist, and struvite, being less stable, is dissolved and/or transformed to another more stable mineral. It is probably for this reason that we rarely find struvite occurring in nature. In fact, struvite only persists in environments with a continuous and/or high supply of organic matter (barns and cemetery soils, lakes rich in organic matter, etc.), which results in a high and continuous precipitation of the mineral, or in the case of the kidney stones due to their ultrastructure, size and habitat. Nevertheless, in most natural environments with low and/or intermittent supplies of organic matter, struvite will form but will not persist. If this hypothesis is correct, the precipitation and subsequent dissolution of struvite might have an important role in the retention and/or maintenance of the bioavailability of $\mathrm{PO}_{4}^{3-}, \mathrm{NH}_{4}^{+}$and $\mathrm{Mg}^{2+}$ ions in soils and sediments. In fact, the excellent properties of struvite as a fertilizer have been confirmed (Priestley et al., 1997), and at present there are numerous research projects focusing on the controlled precipitation of struvite and its later utilization as a fertilizer (Booker et al., 1999). Finally, the precipitation of struvite, even if transitory, would contribute to carbonate precipitation in natural environments rich in $\mathrm{Mg}$ and organic matter, as observed in our culture experiments.

\section{Acknowledgements}

The Swiss National Foundation (SNF) is gratefully acknowledged for generous financial support through grant no. 20067620 . This study was also supported by the Spanish Ministry of Education and Science, project no. CGL2005-03887.

\section{References}

Beavon J \& Heatley NG (1962) The occurrence of struvite (magnesium ammonium phosphate hexahydrate) in microbial cultures. J Gen Microbiol 31: 167-169.
Ben Omar N, Entrena M, Gonzalez-Muñoz MT, Arias JM, Huertas F \& Rodríguez-Gallego M (1996) Morphological diversity of struvite crystals produced by Myxococcus coralloides and Myxococcus xanthus. Tox Environ Tox Chem 53: 209-217.

Benzerara K, Menguy N, Guyot F, Skouri F, Luca G, Barakat M \& Heulin T (2004) Biologically controlled precipitation of calcium phosphate by Ramlibacter tataouiniensis. EPSL 228: 439-449.

Booker NA, Priestley AJ \& Fraser IH (1999) Struvite formation in wastewater treatment plants: opportunities for nutrient recovery. Environ Technol 20: 777-782.

Bouropoulos NCh \& Koutsoukos PG (2000) Spontaneous precipitation of struvite from aqueous solutions. J Crys Growth 213: 381-388.

Braissant O, Cailleau G, Dupraz C \& Verrecchia AP (2003) Bacterially induced mineralization of calcium carbonate in terrestrial environment: the role of exopolysaccharides and amino-acids. J Sed Res 73: 485-490.

Buczynski C \& Chafetz HS (1991) Habit of bacterially induced precipitates of calcium carbonate and the influence of medium viscosity on mineralogy. J Sed Petrol 61: 226-233.

Cailleau P, Dragone D, Girou A, Humbert L, Jacquin C \& Roques $\mathrm{H}$ (1977) Etude expérimentale de la précipitation des carbonates de calcium en présence de l'ion magnésium. Bull Soc Fran Mineral Crystallogr 100: 81-88.

Castanier S, Le Métayer-Levrel G \& Perthuisot JP (1999) Ca-carbonate precipitation and limestone genesis - the microbiologist point of view. Sed Geol 126: 9-23.

Cox AJ, Hukins DWL \& Sutton TM (1989) Infection of catheterized patients: bacterial colonisation of encrusted Foley catheters shown by scanning electron microscopy. Urol Res 17: 349-352.

Dana ES (1997) Dana's Mineralogy, 4th edn (Ford WE, ed). John Wiley \& Sons, New York, NY.

Da Silva S, Bernet N, Delegenés JP \& Moletta R (2000) Effect of culture conditions on the formation of struvite by Myxococcus xanthus. Chemosphere 40: 1289-1296.

Donovan J, Grimm EC, Mueller P, Clark J, Almendinger JE, Engstrom DR, Fritz S, Ito E \& Smith AJ (2005)

Paleohydrological significance of struvite occurrence in midHolocene sediments of Kettle-lake, western North Dakota. Geological Society of America Abstracts with Programs, Vol. 37, No. 7, p 243. Salt Lake City Annual Meeting, 105-111.

Ehrlich HL (2002) Geomicrobiology, 4th edn. Marcel Dekker, New York, NY.

Ferrer MR, Quevedo-Sarmiento J, Béjar V, Delgado R, RamosCormenzana A \& Rivadeneyra MA (1988) Calcium carbonate formation by Deleya halophila: effect on salt concentration and incubation temperature. Geomicrobiol J 6: 49-57.

Ferris FG, Fyfe WS \& Beveridge TJ (1991) Bacteria as nucleation sites for authigenic minerals. Diversity of Environmental Biogeochemistry. Developments in Geochemistry, Vol. 6 (Berthelin J, ed), pp. 319-326. Elsevier, Amsterdam. 
Grases F, Söhnel O, Vilacampa AI \& March JG (1996) Phosphates precipitating from artificial urine and fine structure of phosphate renal calculi. Clin Chim Acta 244: 45-67.

Griffith DP (1978) Struvite stones. Kidney Intl 13: 272-282.

Griffith DP, Musher DM \& Itin C (1976) Urease the primary cause of infection-induced urinary stones. Invest Urol 13: 346-350.

Kofina AN \& Kotsoukos PG (2005) Spontaneous precipitation of struvite from synthetic wastewater solutions. Cryst Growth Des 5: 489-496.

Krumbein W (1979) Phototrophic and chemoorganotrophic activity of bacteria and algae as related to beach rock formation and degradation (Gulf of Agaba, Sinai).

Geomicrobiol J 1: 139-203.

Lowenstam HA \& Weiner S, (eds) (1989) On Biomineralization. Oxford University Press, Oxford.

Lumsden DN (1979) Discrepency between thin-section and X-ray estimates of dolomite in limestone. J Sed Petrol 49: 429-435.

Maier RM, Pepper IL \& Gerba ChP (2000) Environmental Microbiology. Academic Press, San Diego, CA.

McLean RJC, Nickel JC, Noakes VC \& Costerton JW (1985) An in vitro ultrastructure study of infectious kidney stone genesis.

Infect Immun 49: 805-811.

Morita RY (1980) Calcite precipitation by marine bacteria. Geomicrobiol J 2: 63-82.

Morse JW (1983) The kinetics of calcium carbonate dissolution and precipitation. Carbonates: Mineralogy and Chemistry (Reeder RJ, ed), Rev Mineral, 11: 227-264.

Nriagu JO \& Moore PB (1984) Phosphate Minerals. Springer, New York, NY.

Page AL, Miller RH \& Keeny DR, (eds) (1982) Methods of Soil Analysis, Part 2, Chemical and Microbiological Properties. American Society of Agronomy and Soil Science Society of America, Madison, WI.

Parkhust DL \& Appelo CAJ (1999) User's guide to PHREEQC (Version 2) - a computer program for speciation, batchreaction, one-dimensional transport, and inverse geochemical calculations. Water-Resources Investigations Report 99-4259, US Geological Survey, Denver, CO.

Priestley AJ, Cooney E, Booker NA \& Fraser IH (1997) Nutrients in wastewaters - ecological problem or commercial opportunity? Proceedings of the 17th Federal Convention of Australian Water and Wastewater Association 1: 340-346.

Rivadeneyra MA, Ramos-Cormenzana A \& García-Cervigón A (1983) Bacterial formation of struvite. Geomicrobiol J 3: 151-163.

Rivadeneyra MA, Ramos-Cormenzana A \& García-Cervigón A (1985a) Etude de l'influence du rapport Mg/Ca sur la formation de carbonate par des bacteria telluriques. Can J Microbiol 31: 229-231.

Rivadeneyra MA, Pérez-García I, Salmerón V \& RamosCormenzana A (1985b) Bacterial precipitation of calcium carbonate in presence of phosphate. Soil Biol Biochem 17: 171-172.

Rivadeneyra MA, Delgado R, Quesada E \& Ramos-Cormenzana A (1991) Precipitation of calcium carbonate by Deleya halophila in media containing $\mathrm{NaCl}$ as sole salt. Curr Microbiol 22: 185-190.

Rivadeneyra MA, Pérez-García I \& Ramos-Cormenzana A (1992a) Struvite precipitation by soil and fresh water bacteria. Curr Microbiol 24: 343-347.

Rivadeneyra MA, Pérez-García I \& Ramos-Cormenzana A (1992b) Influence of ammonium ion on bacterial struvite production. Geomicrobiol J 10: 125-137.

Rivadeneyra MA, Delgado R, Del-Moral A, Ferrer MR \& RamosCormenzana A (1994) Precipitation of calcium carbonate by Vibrio sp. From an inland saltern. FEMS Microbiol Ecol 13: 197-204.

Rivadeneyra MA, Ramos-Cormenzana A, Delgado G \& Delgado R (1996) Process of carbonate precipitation by Deleya halophila. Curr Microbiol 32: 308-313.

Rivadeneyra MA, Delgado G, Soriano M, Ramos-Cormenzana A \& Delgado R (2000) Precipitation of carbonates by Nesterenkonia halobia in liquid media. Chemosphere 41: 617-624.

Rivadeneyra MA, Párraga J, Delgado R, Ramos-Cormenzana A \& Delgado G (2004) Biomineralization of carbonates by Halobacillus trueperi in solid and liquid media with different salinities. FEMS Microbiol Ecol 48: 39-46.

Rivadeneyra MA, Martín-Algarra A, Sánchez-Navas A \& MartínRamos D (2006) Carbonate and phosphate precipitation by Chromohalobacter marismortui. Geomicrobiol J 23: 1-13.

Robinson H (1889) On formation of struvite by microorganisms. Proc Camb Phil Soc 6: 360-362.

Rosen BP (1987) Bacterial calcium transport. Biochi Biophy Acta 906: 101-110.

Sánchez-Román M, Vasconcelos C, Warthmann R, Rivadeneyra M \& McKenzie JA (2007) Microbial dolomite precipitation under aerobic conditions: results from Brejo do Espinho Lagoon (Brazil) and culture experiments. Perspectives in Sedimentary Geology: A Tribute to the Career of Robert Nathan Ginsburg (Swart PK, Eberli GP \& McKenzie JA, eds), IAS Spec Publ 46, in press.

Stumm W \& Morgan JJ (eds) (1996) Aquatic Chemistry: Chemical Equilibria and Rates in Natural Waters, 3rd edn. Wiley Interscience, New York, NY.

Vasconcelos C \& McKenzie JA (1997) Microbial mediation of modern dolomite precipitation and diagenesis under anoxic conditions (Lagoa Vermelha, Rio de Janeiro, Brazil). J Sed Res 67: 378-390.

Williams S (1999) Struvite precipitation in the sludge stream at Slough wastewater treatment plant and opportunities for phosphorus recovery. Environ Technol 20: 743-748.

Wolt JD (1994) Soil Solution Chemistry: Applications to Environmental Science and Agriculture. Wiley, New York, NY. 